\title{
Women, Intestacy and Forced Eviction: Evaluating Feminist and Judicial Responses in Nigeria
}

\author{
Michael Attah ${ }^{1 *}$, Bertha N. Otunta ${ }^{2}$ \\ ${ }^{1}$ Faculty of Law, University of Benin, Benin City, Nigeria \\ ${ }^{2}$ Michael Okpara University of Agriculture, Umudike, Nigeria \\ Email: *michael.attah@uniben.edu, otuntabertha@yahoo.com
}

How to cite this paper: Attah, M., \& Otunta, B. N. (2021). Women, Intestacy and Forced Eviction: Evaluating Feminist and Judicial Responses in Nigeria. Beijing Law Review, 12, 509-528. https://doi.org/10.4236/blr.2021.122028

Received: March 29, 2021

Accepted: May 9, 2021

Published: May 12, 2021

Copyright $\odot 2021$ by author(s) and Scientific Research Publishing Inc. This work is licensed under the Creative Commons Attribution International License (CC BY 4.0).

http://creativecommons.org/licenses/by/4.0/ (c) (i) Open Access

\begin{abstract}
In Nigeria, the intersection of cultural behaviour, feminist and judicial responses to protection of women from forced eviction upon intestacy is an intertwine of 1) the conflict between full proprietary rights and possessory/rights of use; 2) intrusion of customary institutions into self-acquired property of decedent male family members; and 3) abusive expulsive misapplication of customary precepts by family property managers. We argued that feminist responses, while impugnable for failing to contextualize the problems within cultural structures and erroneously categorizing abuses of customs as part of customs, provide critical theoretical springboard for legislative/judicial action in new situations which may be occasioned by urbanization and expropriation. Conversely, Nigerian courts over the last 60 years have sieved the actual community-accepted inheritance customs to protect women from forced eviction but have preferred a cross-cultural template that entitles women to a possessory life interest. Our conclusion is that while the responses seem conflicting, they support women's rights generally.
\end{abstract}

\section{Keywords}

Women, Intestacy, Forced Eviction, Feminism, Courts

\section{Introduction}

Inheritance has been described as being "so complex" that discussing its nature and implications "is a task fraught with difficulty (Gordon, 2005). Indeed, there may be danger in "homogenizing and imposing a uniform set of practices" throughout a country. Instead, studies show that "variable and locally-specific 
practice continually upset[s] the conventional wisdom... and entails more than simply material goods." (Gordon, 2005). Gordon (2005) notes that inheritance has a major impact on the structural societal level because its practices are a major factor in promoting inequality in society. Consensus thinking is that private property guaranteed by the State was the motor which propelled development (Gordon, 2005; Cooper, 2010). Despite increasing safeguards introduced by statutes, there are more and more disputes in the inheritance sphere. McGregorLowndes and Hannah include among other reasons for this behavior the growing numbers of Generation Y young people living at home into their 20s and 30s who may be classed as "dependent" or "under a disability" as well as cultural groups who value and support extended family arrangements, with associated possibilities for findings of dependency (McGregor-Lowndes \& Frances, 2008). They also identify growing numbers of persons expecting a share of an estate as of right, but who are not included as beneficiaries of a will and may be excluded in a distribution scheme (McGregor-Lowndes \& Frances, 2008; Vaquer, 2010). Contemporarily, the trends in succession law in most jurisdictions have centred on strengthening the spouse's position, maintaining the compulsory share of descendants but aiming at reducing its amount, and the suppression of the compulsory share of ascendants and other relatives (Vaquer, 2010). Yet, it appears that one of the most interesting and controversial issues in intestate succession in Nigeria (as is the case in other parts of Africa) relates to the application of the human rights to the position of women under customary law (Rautenbach \& Meyer, 2010). In Contemporary Nigeria, the advent of individualism has injected a clash of ideologies in the inheritance context. This controversy is three-pronged but intertwined. Firstly, human rights advocacy insists that women whose should have full proprietary rights over intestate estate as opposed to say, possessory or rights of use. Customary structures on the other hand prefer to preserve the communal foundations of land use that entitle a person to only usufruct. Secondly, customary institutions seem to intrude into private or self-acquired property of male members of their family and misapply customary principles of title holding to such properties. This behaviour loses sight of contemporary development which began from the colonial period onwards by which individuals could deal in land commercially for money or obtainment of credit for other purposes. Thirdly, there are abuses of customs such that male-members with management functions over family land try to exclude women from even their possessory rights. Nigerian courts have had to deal with these problems. Preliminarily, we argue that feminist advocacy for equality in Nigeria fails to contextualize the problem within the cultural structures in which human rights norms are engaged upon intestacy. In the zeal to protect women, it erroneously categorizes abuses of customs as part of the custom. The result is a negative perception of customary institutions and structures as being anti-human rights. Nonetheless, we opine that this strict feminist approach provide effective theoretical springboard for legislative judicial action in the face of new situations such as urbanization and expropriation. The 
courts on the other hand have adopted a mid-way, conciliatory approach. Over the last half a century and more, it has endeavoured to ascertain the actual inheritance customs as accepted by communities involved to protect women from forced eviction but has preferred a cross-cultural template that engages the right of women within the cultural framework of communal/family land holding that entitles women to a possessory life interest as applicable to all family members.

In Section 2 of this paper, we highlight some cultural factors that may conduce to the abusive behaviour of forced eviction and how this could infringe human rights prescriptions. In the first part of Section 3, we review the bases of feminist advocacy for functional equality upon intestacy alongside the impact of abuses on the right to housing. This part will further show what these views ignore. In the second part of Section 3, we analyze a number of judicial decisions to demonstrate the preservative approach of the courts. The second part of this section will present situations that could negatively impact on women's rights to share in proceeds of sale of family property as well as their right to compensation in the event of expropriation. The judgments do not contemplate these situations. Section 4 will be the conclusion.

\section{Contextualising the Problem of Forced Eviction in Nigeria}

In this section, we highlight some cultural factors conducing to the abusive behaviour of forced eviction as well as the extent to which Nigerian law provides against this. Thereafter, we will identify some problems with the scholarly views relating to how women upon intestacy should be protected.

Generally, with only a few exceptions, customary structures of property holding are male-centred and patrilineal (Levy \& Pinto, 2011-2012). One explanation for this could be that marriage is generally virilocal-leaving only male members to protect, manage and continue to put family property to use (Cooper, 2010). Another is that customary law of property ownership is founded on communalism which fosters group rights, group land holding and intra-family social cooperation and mutual welfare support (Diala, 2014). One undeniable psyche among male members of families is that property (land) belongs to men and women should enjoy housing rights only functionally and not as title holders. Abuses of this thinking could include forceful ejection of females (widows and children) from matrimonial homes and other landed property which they accessed during the currency of marriage. This type of behaviour will violate the right to freedom from forced eviction-a component of the right to housing. While the 1999 Constitution recognizes as fundamental the right to acquire and own immovable property (section 43) this is not the case with the right to housing. The closest is section $16(2)(\mathrm{d})$ which mandates the state to direct its policy towards ensuring "that suitable and adequate shelter...[is] provided for all citizens." It is thus provided only as one of the fundamental objectives and directive principles of state policy-and not as an enforceable right. A few states in the 
country have enacted laws targeting abusive widowhood practices; this however, represents a small percentage and provisions on forced eviction are not robust where they exist. However, in international law, one of the first references to the right to housing is in article 25 (1) of the Universal Declaration of Human Rights. The International Covenant on Economic, Social and Cultural Rights 1966, widely considered as the central instrument for the protection of the right to adequate housing, refers to the right of everyone to an adequate... housing, in its article 11. Other international and regional Instruments also contain this right. (CERD, 1965 art 5(e)(iii); CEDAW, 1979 art 14(2)(h); the CRC, 1989 (art 27(3); CRSR 1952 art 21; ICPMWMF 1990 (art 43(1)(d); CRPD 2008 arts 2, 5(3), 9(1)(a), 22(1), 28(1) \& 28(2)(d)). With regards to the African Charter on Human and Peoples' Rights 1981, in SERACv. Nigeria (communication No. 155/96), the African Commission on Human and Peoples' Rights found that, while the right to adequate housing was not explicitly recognized in the Charter, it could be inferred from other rights (such as art.s 14, 16 and 18(1)) because when housing is destroyed, property, health, and family life are adversely affected. (Communication 155/96, 2003) The advocacy and support for a right to adequate housing is strong (Chenwi, 2013; CESCR General Comment No. 4; Office of the United Nations High Commissioner on Human Rights; Mercy Law Resource Centre, 2018). This is in spite of arguments to the contrary: (Adams, 2009). Williams (2014) propounds however that human rights discourse alone provides limited analytical assistance in addressing the difficult economic and institutional questions that must be faced in order to make housing rights a reality.

\section{Protecting Women from Forced Eviction}

\subsection{What Feminist Reponses Say}

Feminist jurisprudence in Nigeria draws attention to the correlations between the insecurity of women's land rights and social and economic vulnerabilities and is awash with opinion that strongly suggests that customary law of inheritance truncates women's right to inherit, thereby affecting other rights, including the right to life, housing and dignity (Okoboh, 2005; Odiaka, 2013; Chinwuba, 2015; Nwufo \& Okoli, 2016). It has even been asserted that "Women may be allowed to cultivate plots of land belonging to their male relatives (husband or father) but they are not allowed to own land, whether by inheritance or purchase" (Nelson \& Nelson, 2010). However Mann (1991) shows that commercialization of, and expansion in, international trade in post-slave trade colonial Lagos resulted in a struggle between men and women over land resources both inside and outside the household. These factors underscored the shift from communal land ownership to private/individual ownership of land to secure credit for trade (Mann, 1991).

Dada (2014) contends that most cultures in Nigeria do not afford women with rights such as afforded by international instruments and local laws including the Constitution. Without contextualizing these problems, she isolates the primoge- 
niture rule, exclusion of widows from succession (even though she admits that she is entitled to be maintained from the proceeds of the deceased husband's estate), daughter retention (Nrachi or Nnaeto customs) and labels them as unlawful (Dada, 2014). Her views published in 2014 fail to take cognizance of judicial progress which has been made to protect women from abuses in some communities (Dada, 2014). Basing his critique on section 42 of the 1999 Constitution and other non-discrimination and equality provisions of CEDAW, ICCPR and ACHPR, Edu (2016) frowns at some customary inheritance rules in the Southeastern states of Nigeria including the Oli-ekpe custom (which allows nearest paternal male relative to inherit as against biological female children) and the rules that appear to exclude females as being contrary to natural justice, equity and good conscience (Edu, 2016). His scathing remarks on these customs are that they negate the right to equality and consequently the dignity of victims. The effect is to subject women to the status of second class citizens (Edu, 2016). Interestingly, he admits one important context of application of inheritance rules at the outset of his work: Patrilineal society and the diversity in rules (Edu, 2016). Ojikere and Chuan (2015) regard denial of inheritance and proprietary right as an abuse of the dignity of women in Nigeria as provided in section 34 of the 1999 Constitution (Ojikere and Chuan, 2015). They assert that the attitude of the courts to law generally (a positivist ideology), section 6(6)(c) and the non-domestication provision of section 12 of the 1999 Constitution constitute a setback and an affront to the protection of dignity of women (Ojikere and Chuan, 2015). Particularly, they frown that the economic social and cultural rights (ESCs) necessary to guarantee dignity upon intestacy remain judicially unenforceable as Part II rights. Nonetheless, this whining over non-justiciability of Part II rights pretends as though women who have been treated with indignity do not have remedies before the courts outside ESC rights regime. Inheritance and property rights are in the realm of private law and the court will be prepared to make particular applications of section 34 of the Constitution where it is necessary to do so. This is in addition to the judicial strides and gains which have been made in the application of the non-discrimination right under section 42 of the same Constitution and the proscription of abusive succession practices under some state laws. Diala (2018) critiques the judicial failure to subject customary inheritance rules to constitutional scrutiny using the Bill of rights (Diala, 2018). He claims that this preservative philosophy of the Supreme Court evident in decided cases in unsuitable to contemporary conditions. Interestingly, he provides the culturo-utilitarian perspectives of customary law of property holding which provides a good basis for understanding the underpinnings of these practices:

The agrarian societies in which these rights emerged were founded on families living in close-knit units. This arrangement was mainly for agricultural and defence purposes, given that family wealth was jointly generated. In this setting, the best interest of the family was paramount. To perpetuate clan lineage and keep wealth within the family, therefore, heirs inherited 
not only the property of deceased persons, but also the responsibility to maintain their dependents. Accordingly, the male primogeniture custom was aimed at caring for the family... (This arrangement gave) women neither the need nor the opportunity for independent property acquisition. After observing this social setting, colonial courts concluded that women's matrimonial property rights were subsumed in their husband's rights thereby producing the official customary law that women may exit marriage only with their clothes and cooking utensils (Diala, 2018).

He opines that this social structure "negatively affects women's matrimonial property rights due to its preservative philosophy, the patrilocal nature of customary marriage and the influence of socio-economic changes such as urbanization, acculturation and independent income. It is not true that the courts fail to utilize the Bill of Rights in the Constitution to assess customs Ironically, he discusses a good number of judicial decisions where inheritance customs were subjected to constitutional scrutiny. He also argues that judges apply customary law with their understanding of the law and its role in society (Diala, 2018). This is wholly unfounded. Indeed, he spends a section of the work analyzing the process of establishing customary law before the courts. Customary law is a matter of proof by evidence; (Diala, 2018; Sections 16-18 Evidence Act 2011) and as he rightly argues, such proof enables the past and present social settings of customs to be properly articulated and their foundational values revealed." (Diala, 2018). The essence of "proof" by evidence before a court can act on a custom is to lay out the cards on the table for the court's scrutiny. Where there are changes which a widow observes and which the area affected by the custom has applied, she is free to bring this to the attention of the court. Interestingly, the Evidence Act seems to envisage that changes could affect the content of a customary rule or its manner or method of application. Section 19 provides that "every fact is deemed to be relevant which tends to show how in particular instances a matter alleged to be a custom was understood and acted upon by persons then interested." Contrarily, he claims that judicial notice of customary rules as permitted by the Evidence Act 2011 robs widows of the opportunity to explain 1) the foundations of male primogeniture custom and how this custom is accompanied by heirs' duty to support a deceased person's dependents 2) how acculturation, urbanization and other socio-economic changes make it difficult to fulfill this duty of care. Ezer (2016) supports assertion. She gives what may be considered examples of these changes namely: "changing roles of women in the modern world" and the "restructuring of families along nuclear lines." Due to this, "an heir does not always live with all his extended family. He may therefore, not be best suited to take on the customary social responsibilities that come with the family property even if he wanted to." (Ezer, 2016). Urban migration may often be responsible for this. Nonetheless, this view is flawed. Urbanization and improvements in infrastructure-roads-transportation, information and communication technology, efficient financial systems-banks, all make it possible for a person to per- 
form traditional roles from anywhere. His physical presence may usually be unnecessary. With regard to the negative results of judicial notice of custom asserted by Diala, it is indeed not mandatory that once a custom has been given in evidence in a superior court, it is automatically judicially noticed. The provision in section 17 states that it may be judicially noticed (subsequently by other courts). A subsequent court to whom it appears that there are intervening factors or developments with regards to the application of a customary rule should be at liberty to listen to the party alleging such development and consider whether the new evidence represents the current rule. This is in accord with the very nature of customary law. Overall, the tenor of the Evidence Act 2011 is that the law leaves it to the party alleging how a custom is applied or asserting its inapplicability to establish it before the court.

Ezer (2016) considers the non-codification or the absence of official records of customary law and lack of uniformity in their application problematic because, according to her, they lead to differing interpretations depending on the circumstances. While she claims that this "ambiguity" is widely used to disempower women and promote patriarchy, she however concedes that customary law can be a source of accessible justice and norms responsive to community needs; and "regardless of one's opinion of customary law, it is the law governing the lives of majority of people on the African Continent, and a focus on it is critical to ensure human rights protections for African women....” (Ezer, 2016).

In the next part of this section, we consider why generally, the above views should be accepted with caution given their holistic condemnation of customary intestacy regimes.

\subsection{What Feminist Responses Ignore}

Ezer's postulation above indicates the utilitarian value of customary precepts including intestacy rules. Given this reality, it is not enough to swiftly condemn a regime without engaging how individuals (particularly, women in this case) perceive the regime. Some of the contributions seem to oversimplify the issues involved in the application of human rights to inheritance. The interaction between human rights norms and cultural behaviour creates complex and delicate problems that cannot be resolved by simply insisting that the tenets of human rights be absolutely applied to women in every intestacy situation. For instance, patrilineal systems/patterns of inheritance are occasioned by certain structures which even feminists have refused to challenge. They seem to have "accepted" them as normal. An instance is the attitude of women in Nigeria to the bride-price (dowry/marriage symbol) institution. Many consider it so important to womanhood that it should be untouched. (Ezeilo and Alumanah, 2008; Enemo, 2008; Obi, 2008; Ezeilo and Nwadioke, 2008). Specifically, Asogwah (2008) interviewed 10 women on their views on bride-price. His findings were that only one of the women (a nurse) spoke in favour of abolition of bride price because she felt it was repugnant to natural justice equity and good conscience. The other 
nine (all professionals) endorsed bride price because it gives them a measure of respect and a sense of [self] worth in their husband's home (Asogwah, 2008). Nwoke (2008) shares these views adding that there is a psychological link between bride price and the socio-economic growth, development and well-being of the Nigerian woman. Onyeneho (2008) shows that while women decry the idea of being regarded men's property due to payment of bride price, they endorse the institution due to the psychological (sense of dignity) benefits. Another interesting theme which is often mentioned and yet glossed over is the patrilocal pattern of marriages in Nigeria. This feature of African customary law is usually identified as a given and normal. Yet when the issues relating to marriage and inheritance are evaluated, it is one of the fundamental underpinnings that defined cultural structures that facilitated the male-bias inheritance rules. Pragmatically, if marriages remain patrilocal, it will be difficult to achieve an upscale revolution of patriarchal inheritance regimes. If it is not perceived as discriminatory, then it may be that human right norms in the inheritance context can only inevitably be applied with some relativism as opposed to the wholesale equality advocated by scholars. Ezeilo (2004, 2013/2014, 2018) supports such an approach and calls it a "cross-cultural dialogue." According to An-Na'im and Deng (1990), contextualized cultural approach is the appropriate means to promote universal recognition of the concept of human rights so that alternative sources and interpretations within any given tradition may prove useful in overcoming the problems raised by a particular tradition. Finally, family linkages (particularly through blood) are fundamental to property holding in cultural contexts in Africa. In their introductory comments, Kutsoati and Mocrk (2012) state that in much of sub-Saharan Africa, the idea of a family extends beyond its conjugal members and that a person's relationship with members of his extended family may be "as important as, and in some cases, more important than, one's relationship with one's spouses and children. Historically, lineages are bastions of emotional and financial support." (Kutsoati and Mocrk, 2012). This is supported by the findings of studies conducted in Ghana by Fenrich and Higgins (2001). The general rule is that once a family is created under customary law, it is an extended family system where corporate membership is established (Olomola, 2010). This means that various related families make up the social institution and a person may have rights and obligations in the general unit thereof; and not just in his immediate nuclear family (Nwogugu, 2014). Nwogugu (2014) notes that the extended family possesses some sort of legal personality and may own and hold property, sue and be sued as a corporate entity. It is responsible for the authorized acts of its agents as a result of the corporate feature. One primary mode of membership is by birth into the family; covering all legitimate children born into each nuclear family (Nwogugu, 2014). Another mode of membership is marriage. In patrilineal societies which is the more common, a woman, upon marriage, becomes a member of her husband's family and acquires certain rights and obligations therein. This membership does not cease even with the death of hus- 
band-which ordinarily should end the relationship. But because she is married "into the family" she retains her membership and continues to enjoy, along with her children, what was due her husband. In the light of these types of benefits, Chianu (2019) concludes that when cases are evaluated individually, communal institutions seem to secure something better than the cold words of statutes. According to him, the statutes sometimes ignore social and economic progress and other prevailing circumstances affecting a community (Chianu, 2019). In the same vein, the United Nations Human Settlements Programme (2006) made concrete observations regarding the limits of influence of laws on issues embedded in the social and cultural thoughts of a people. In relation to ensuring women's equal rights to property and access to resources which are critical in the fight against poverty and securing women's inheritance and housing rights, it stated that

[t]he formal codification of rights, even if constitutionally enshrined, does not guarantee their implementation by women... It is argued that rather than formal equality in access to land, specific affirmative measures are needed to rectify the discriminatory practices of the past as well as present day obstacles for the majority of women. These measures must be targeted towards women's specific experiences, needs and priorities rather than a mere existence of Constitutional principles must generate gender responsive laws and regulations, awareness and empowerment and require supportive judicial interpretation and enforcement. A variety of creative approaches within countries are needed to ensure that women can claim their rights. This progress report through its brief contextual summary, the tabulated status of constitutional provisions and diverse results raises several questions as to why particular countries have chosen particular positions (UN-HABITAT Progress Report, 2006).

\subsection{What the Courts Have Done}

Nigerian courts have had a number of opportunities to deal with the issue of forced eviction. The approach has generally been to ascertain the true rule of customary law and to engage in a balancing activity. While they protect the victim of abuse, they have done so within the context of culturally accepted rules of intestacy.

The earliest judgment appears to be Nezianya v Okagbue (1963). After the death of her husband, a widow started letting out houses to tenants. Later on, she sold a portion of the land and with the proceeds, built two huts on another portion of the land. When she wanted to sell more parcels of land, her husband's family objected. She devised the disputed land to her late husband's daughter's child, Mrs Julie Nezianya, who sued the husband's family. The devisee sought exclusive possession of the land, claiming that her grandmother had had long, adverse possession of it. The trial court held that possession by a widow of her husband's land cannot negate the rights of her husband's family as to enable her 
acquire an absolute right of possession against the family. The Supreme Court ruled that

the essence of possession of the wife in such a case is that she occupies the property or deals with it as a recognized member of her husband's family and not as a stranger; nor does she need express consent or permission of the family to occupy the property so long as the family makes no objection ... The consent, it would appear, may be actual or implied from the circumstances of the case, but she cannot assume ownership of the property or alienate it. She cannot, by the effluxion of time, claim the property as her own. If the family does not give their consent, she cannot, it would appear, deal with the property. She has, however, a right to occupy the building or part of it, but this is subject to good behavior (Nezianya v Okagbue, 1963).

These principles were restated in Nzekwu v Nzekwu (1989). In this case, the deceased left a wife and two female children. Mrs. Nzekwu's in-laws sold the disputed land and the purchaser gave it out to tenants. The Court of Appeal held that a widow without a male child who chooses to retain her husband's name has the right to reside in the matrimonial home even if she is childless. She also has the right to use her matrimonial property as long as her rights do not negate the rights of her late husband's family. On appeal, the Supreme Court ruled that a widow has the right to reside in the matrimonial home, to be given farm land for cultivation, and to be supported by her husband's family. However, it affirmed the relativity of a widow's rights. According to Nnamani JSC,

The rights of a widow in her husband's property in customary law have been settled. A widow who chooses to remain in the husband's house and in his name is entitled, in her own right and notwithstanding that she has no children to go on occupying the matrimonial home and to be given some share of the farmland for her cultivation and generally to maintenance by her husband's family. Should her husband's family fail to maintain her, it seems that she can let part of the house to tenants and use the rent obtained thereby to maintain herself. Her interest in the house and farmland is merely possessory and not proprietary, so that she cannot dispose of it out-and-out Nzekwu v Nzekwu (1989).

It approved the conclusion of the trial court that no member of her husband's family had the right to dispose of the property at least while she was alive. The court ruled that any Onitsha custom which postulated that the $1^{\text {st }}$ son had the right to alienate as the Okpala, property of a deceased person in the lifetime of the widow should be regarded as repugnant to equity and good conscience. In (Mojekwu v Mojekwu, 1997; Mojekwu v Iwuchukwu, 2004) the appellant claimed right of occupancy over the disputed property on the basis that under the oli-ekpe (primogeniture) custom of Nnewi, the brother of a man without a male child inherits his estate, even where the deceased had female children. The High Court dismissed his suit. Notably, the parties did not request the invalidation of the 
oli-ekpe custom, nor did the trial court address it. In dismissing the appeal, the Court of Appeal, on its own, invalidated the oli-ekpe as repugnant to natural justice, equity and good conscience The Supreme Court ruled that this invalidation was improper since it was not founded on the claims of the parties. Importantly, the Supreme Court reasoned that the engagement of cultural structures and human right norm is often not so simple:

A custom cannot be said to be repugnant to natural justice, equity and good conscience just because it is inconsistent with English Law concepts or some principle of individual rights as understood in any other legal system... Admittedly, there may be no difficulty in reaching a decision in some obviously outrageous or needlessly discriminatory customs. In some other cases, it may not be so easy. The (lower court) was no doubt concerned about the perceived discrimination directed against women by the said Nnewi oliekpe custom and that is quite understandable. But the language used made the pronouncement so general and far-reaching that it seems to cavil at, and is capable of causing strong feelings against all customs which fail to recognise a role for women-for instance, the custom and tradition of some communities which do not permit women to be natural rulers or family heads. The import is that those communities stand to be condemned without a hearing for such fundamental custom and tradition they practice by the system by which they run their native communities. It would appear for these reasons that the underlying crusade in that pronouncement went too far to stir up a real hornet's nest even if it had been made upon an issue joined by the parties, or properly raised and argued (Mojekwu v Iwuchukwu, 2004).

In 2014, Anekwe v Nweke was decided by the Supreme Court. It further sent a message that abuses to customs which engender discrimination or oppression and tend to be usurpatory would be struck down by the court. The respondent's husband was the brother of the $1^{\text {st }}$ appellant. The two men were the only sons of their father but from two different mothers. Sometime after their father's death, their uncle, who had taken them in, built houses on their father's land and settled them there. The respondent contended that the uncle built two separate bungalows and shared/partitioned them between the two men. On the death of her husband, she inherited his portion where he was buried. Eventually, the $1^{\text {st }}$ appellant) asked her to vacate the portion since she did not have any male child. According to her, a widow inherits her husband's property whether she has a male child or not under $A$ wka custom. On the other hand, the defendants/appellants contended that the uncle only built mud houses and that $1^{\text {st }}$ appellant built the two houses and gave the respondent two rooms to occupy as a tenant at will. He claimed to have inherited the entire land as the first and only surviving son of their father. Before the action in court, the matter was arbitrated by the $O z O$ Awka Society-the highest dispute settlement body—which ruled in favour of the respondent which was upheld by the Supreme Court. According to Ogunbiyi 
JSC,

... [the appellants] have admitted that the respondent is the widow of the deceased.... On a careful perusal of the totality of the appellants' pleadings therefore, it is obvious that their top most priority was the preservation of the age-old, male dominated custom and cultural practices of Awka people on inheritance.... The averments are clear vindication of the respondent that the appellants' intention is to disinherit her from the entitlement of her late husband's property.... [T] he complaint...at the trial court was not limited to whether the compound... was partitioned between the father of the appellants and the husband of the respondent or whether it remained one compound, but rather and more importantly it also raises the question, "whether the respondent who has no male child can inherit the property of her late husband?" (Anekwe v Nweke, 2014; Also, Mojekwu v Ejikeme, 2000; Asika v Atuaya, 2008).

The court endorsed the outcome of the arbitration by Ozo Awka Society. The verdict was contained in the evidence of P.W.1 to the effect that "the plaintiff is entitled to live in the husband's compound.... Under Awka custom if a man dies without a male child, the wife will not be driven away from her husband's compound." (Anekwe v Nweke, 2014). Their Lordships spared no words in condemning appellants' version of the Awka custom. Ogunbiyi JSC's view is representative and deserves extensive quote:

The custom and practices of the Awka people upon which the appellants have relied...is hereby outrightly condemned in very strong terms... Any culture that disinherits a daughter from her father's estate or wife from her husband's property by reason of God instituted gender differential should be punitively and decisively dealt with... For a widow of a man to be thrown out of her matrimonial home, where she had lived all her life with her late husband and children by her late husband's brothers on the ground that she had no male child is indeed very barbaric, worrying and flesh skinning... The impropriety of such a custom which militates against women particularly widows, who are denied their inheritance, deserves to be condemned as being repugnant to natural justice, equity and good conscience.

The spirit behind these statements must be commended. The judgment serves as a platform for redress for women who suffer abusive acts of discrimination from male members of their extended families. However, it is important to point out that in the zest to condemn the behavior of the appellant, the court lost sight of the fact that it was utilizing an abuse of the custom to condemn the whole. Indeed what the Supreme Court did was to endorse the ruling of the Ozo Awka Society which had correctly applied the custom in its fullness to the case of the respondent. In other words, the court actually upheld a part of the Awka custom to the effect that a widow is entitled to reside in matrimonial home while she is alive. The court referred to the case of Nzekwu v Nzekwu (1989) to this effect: a 
widow has a "right of possession of her late husband's property and no member of her husband's family has the right to dispose of it or otherwise whilst one is still alive." (Anekwev Nweke, 2014).

\subsection{The Position of the Courts and Some Practical Considerations}

In addition to the normative underpinnings of the judgments of the courts above, some practical bases for the relative property rights of the widow or female children can be found in situations where the widow has no issue and later remarries or where her female children leave the natal home because of marriage. In such instances, an absolute right to inherit will be desultory. It could create an awkward situation where property is not put to good and economic use. Furthermore, the courts are not oblivious of the distinction between selfacquired property and those bestowed on a person through partition of family property as well as the "family compound" concept or ancestral property to which principles of communal land holding would strictly apply. The former are private property which may disposed of at will. The latter are not subject to disposition by any member of the family including a widow. It is this category that male members insist are not inheritable in the strict legal sense. Nonetheless, she enjoys, as Anaekwe's case indicates, possessory interests over her husband's holdings for life (Attah, 2015-2016). This fine distinction is recognized in a number of customary laws in the South-Eastern Nigeria. For example, in Odiariv Odiari (2009), it was established that under the Onitsha customary law of inheritance, the eldest son's right to inherit the Iba (family house) was subject to his mother's (widow's) right to possession during her lifetime. This was determined by the court to include the right to collect rent from other parts of the Iba. The $1^{\text {st }}$ respondent and the other children of the marriage were granted Letters of Administration over the estate of the deceased to the exclusion of the appellant. The appellant did not deny the widow's right to reside on the $1^{\text {st }}$ floor of the $I b a$ along with his other unmarried sisters but it denied her right to the rent of the other flats in that building. It also proposed that on the death of the widow, the unmarried sisters were to vacate the Iba and reside in another flat in another building of the deceased. The respondents' scheme was in accordance with Onitsha Customary Law. The Court of Appeal relying on scholarly works concluded that a widow has a right to possess the family house for life; there was therefore no contradiction in the rights of the Appellant and the $1^{\text {st }}$ respondent widow. It stated

Inheritance...enures for ever the right of the inheritor to the inherited property while right of possession is identified clearly for the life of the recipient. The issue is therefore at what time the right to inheritance commences. It commences on the death of deceased subject to the right of possession of the widow for her lifetime... In the instant case, it should not be difficult for a child of the widow to allow the mother to reside and use the house during her lifetime. The right to absolute inheritance of the family house remain(s) 
with and in the eldest son, the head of the family. It is not contested by the respondents that the appellant is the head of family; the issue which arises is whether the appellant is to take over possession of (the family house) when his mother...still reside(s) therein (Odiariv Odiari, 2009).

It further held that the right to possession "includes a right to collect rent on the premises but does not convey to the widow a right to sell or dispose of any part of the property." (Odiariv Odiari, 2009).

Furthermore there are some circumstances which statutory intestacy rules and customary law may not have contemplated. The courts have astutely disregarded what those rules provide in search of pragmatic solutions based on equity. In Okonkwo v Okonkwo (2014) the appellant's only child died in 1986. Her husband had four children by another woman whom the respondents insisted was married to the deceased under customary law. Upon the death of the deceased, the respondents took over the title documents and the deceased three landed properties insisting that customary law should apply to the devolution of the deceased's estate since he had conducted his life in accordance with native law and custom and the properties were either family land or should be inherited by the deceased first son in trust for his blood relatives including the appellant. The trial court applied section 120(1)(b) of the Administration and Succession (Estate of Deceased Persons') Law (1986) to award only $1 / 3$ of the estate to the deceased's wife. The counsel to the appellant in his argument on appeal pointed out the lacuna and injustice in the above provision to the extent that the law did not contemplate a situation where the decedent leaves a wife without any issue of the marriage but has children from another woman. In such a case, the children of the unlawful union will take $2 / 3$ of the estate only to leave the legitimate wife with only $1 / 3$ for her life or until she remarries (Okonkwo v Okonkwo; Widowhood Law 2005; Obusez v Obusez, 2001). He contended that this injustice will be more acute where as in this case, the properties were self-acquired and the widow contributed to their acquisition or erection. The Court of Appeal agreed. The court held that the deceased could not have been subject to customary law given that his lifestyle indicated otherwise: he married the appellant under the Act; his children were baptized in the church as evidenced by their baptismal certificates; and his funeral rites were observed in the church. He had thus changed his personal law necessitating that the distribution of his estate would be by English law. With regards to the applicable law for distribution, the court stated:

The one third is not even absolute but subject to her life or remarriage whichever comes first.... Section 120(1)(b) of the Administration and Succession (Estate of Deceased Persons') Law of Anambra State 1991 no doubt to the extent that it discriminates or dichotomizes between male and female intestate spouses in inconsistent with section 42(1)(a) of the 1999 Constitution... and to the extent of such inconsistency ought to be void. This is because by providing that only one third of the estate of the intestate shall go 
to "the surviving spouse whose interest shall be absolute in the case of a husband or for her life or until her remarriage (which ever first occurs) in the case of a wife," the widow is put under great disadvantage particularly in the case of this widow who had toiled all these years with her husband and invested her life savings in building the estate now in dispute only for her to be entitled only to a life interest of one third of the estate and the bulk of the residue of two thirds of the estate shall devolve on the children of an adulterer who will now enjoy same absolutely. Definitely, since the Anambra State Succession Law did not envisage this unwholesome scenario, this court ought to seek for the aid of equity and other legislations that will ameliorate the hardship of the provisions of section 120 of (the law) in order to do justice to a childless widow like the appellant (Okonkwo v Okonkwo, 2014).

And it did. It called in aid the provisions of section 4(3) of the Widowhood Law of Anambra State 2005, (prohibiting forceful dispossession of matrimonial property), Obusez v Obusez, section 36 of the Marriage Act 1914 and the Statutes of Distribution 1670 and 1685 as modified by the Intestates Estates Act 1890, para 4 (entitling a widow to one half of the decedent husband's estate) to award half the estate absolutely to the appellant. More recently, the courts have upheld the rights of widows to sue and protect the properties of their deceased from waste and intruders (Koladev Ogundokun, 2017; Mohammedv Klargester (Nig) Ltd, 2002; Ruthlinz Inter' 1 Invest. Ltd v Stella Ihebuzor, 2016; Airtel Networks Ltd. v George, 2015; Johnson v Ogunbi, 1980; Okonyia v Ikengah, 2001).

On the whole, even though some do not agree (Durojaiye, 2013), it can be said that courts score a pass mark in protecting women from forced eviction in the face of abusive behaviour. Nonetheless, the judgments are not all-cure as they could become ineffective in protecting women in other situations not within the purview of the rules set forth in the cases.

\subsection{What the Judgments Have Not Contemplated}

Despite these interesting judgments, can it be said that the court have done enough? It is our view that the approach of a number of scholars reviewed above has its merits which these judgments have neither contemplated nor captured. These focus on the status and ramification of possessory rights in the face of future events. The first situation is the case of disposition of the property subject of a woman's possession or life interest. One observable economic and demographic behaviour is rural-urban migration resulting in expansion of cities due to increasing population. A result of this is that more and more rural communities are merging with cities as housing needs of the urban population increases. One outcome of this is that the commercial value of land is enhanced and communities realizing the advantages of land commercialization are demystifying the aura of the once revered cultural structures of land holding. In some places, communal and family lands have been partitioned and sold out to companies and 
individuals for "developmental" purposes. In some instances, where family members no longer reside in their rural zones, the homestead or family compound which was regarded as sacred have been disposed of. In this setting, insisting that women retain only possessory rights of use will smother their economic welfare. They should be able to share in the proceeds of sale as equal members of family. Secondly, the 1999 Constitution clearly preserves the right of citizens to acquire and own immovable property in any part of Nigeria, and only permits the compulsory acquisition of moveable and immoveable property under a legal regime that ensures the prompt payment of compensation and access to justice for the person claiming compensation (sections 43 and 44). The Land Use Act 1978 allows expropriation for overriding public interest which includes pubic purposes (section 28). The compensation regime under section 29 the Act is segregated. A distinction is drawn between "holder" and "occupier" for the purpose of compensation. The structure of the regime is such that in some instances, both the holder and occupier are entitled to compensation for their unexhausted improvements and in other instances only the holder or occupier is entitled. The implication is that if a woman upon intestacy is deemed not to have any proprietory interest, but regarded only as a "user" she may not qualify to receive compensation either as holder or occupier as the family could present a corporate front in the event of expropriation. It is imperative that the "possessory life interest" which courts have endorsed for women in the circumstance of intestacy should be interpreted in harmony with the strict feminist approach. In that case, she will be a "holder" or a titled "occupier."

\section{Conclusion}

It appears from scholarly views sampled in this study that feminist responses to forced eviction assess inheritance customs with the gauge of universal and absolute interpretations of internationally and constitutionally accepted human rights norms and standards such as equality, non-discrimination and full property rights for all. They however ignore the need to identify the true rules of customary law that may actually be beneficial to women in the inheritance context. Yet we have argued that this approach may become useful for women in situations of urbanization and expropriation. The courts on the other hand have sought to discover the true customary rules on a case by case basis and have preferred to apply them in resolving issues of forced eviction involving women. The result is that the courts preserve family/communal rights while giving women possessory rights. We have argued that this approach is beneficial for all involved and protects women's housing rights to a large extent. Moreover, the position of the courts appears certain. There is no doubt that law cannot ask or answer all the questions which may usually be raised about a people's cultural behaviour. Indeed, norms and tenets which guide cultural behaviour are unwritten and ingrained in the minds of those guided by them so that it is difficult for law to legislate on those aspects. Nonetheless, human rights precepts and laws founded 
on them are important in protecting individuals from abusive behaviour and can provide important reference points for redress. It is possible that over time legal prescriptions can affect cultural attitudes to the behaviour legislated against. On this footing we suggest that constitutionally, the right to housing should be elevated to a first generation right but local authority bye-laws should legislate against forced eviction upon intestacy, providing an enforcement role for traditional institutions closest to the people.

\section{Conflicts of Interest}

The authors declare no conflicts of interest regarding the publication of this paper.

\section{References}

Adams, K. D. (2009). Do We Need a Right to Housing? Nevada Law Journal, 9, 275-324.

An-Na'im, A. A., \& Deng, F. (1990). Human Rights in Africa Cultural Perspectives. Washington DC: The Brookings Institute.

Asogwah, F. (2008). The Bride-Price Controversy, Multiple Marriages and the Offence of Bigamy. In J. N. Ezeilo, \& J. E. Alumanah (Eds.), Bride Price and the Implications for Women's Rights in Nigeria (pp. 41-54). Enugu: Women Aid Collective.

Attah, M. (2015-2016). State Protection of Individual Interests in the Family: An Evaluation of Recent Judicial Decisions in Nigeria's Family Law. Nigerian Current Law Review, 176-203.

CESCR General Comment No. 4: The Right to Adequate Housing (Art. 11 (1) of the Covenant). Adopted at the Sixth Session of the Committee on Economic, Social and Cultural Rights, on 13 December 1991 (Contained in Document E/1992/23).

Chenwi, L. (2013). The Right to Adequate Housing in the African Regional Human Rights System: Convergence or Divergence between the African Commission and South African Approaches. Law Democracy and Development, 17, 342-362.

Chianu, E. (2019). Law of Succession. Lagos: New System Press.

Chinwuba, N. N. (2015). Ending Inequality in Nigeria: A Refreshing Approach from the Nation's Judiciary. International Journal of Law, Policy and the Family, 29, 341-350. https://doi.org/10.1093/lawfam/ebv010

Cooper, E. (2010). Inheritance and the Intergenerational Transmission of Poverty in Sub-Saharan Africa: Policy Considerations (pp. 1-34). Chronic Poverty Research Centre Working Paper No. 159. https://doi.org/10.2139/ssrn.1719673

Dada, F. O. (2014). The Justiciability and Enforceability of Women's Rights in Nigeria. Global Journal of Human-Social Science (E), 14, 49-56.

Diala, A. C. (2014). Reform of the Customary Law of Inheritance in Nigeria: Lessons from South Africa. African Human Rights Law Journal, 14, 633-654.

Diala, A. C. (2018). A Critique of the Judicial Attitude towards Matrimonial Property Rights under Customary Law in Nigeria's Southern States. African Human Rights Law Journal, 18, 100-122. https://doi.org/10.17159/1996-2096/2018/v18n1a5

Durojaiye, E. (2013). "Woman, But Not Human": Widowhood Practices and Human Rights Violations in Nigeria. International Journal of Law, Policy and the Family, 27, 176-196. https://doi.org/10.1093/lawfam/ebt001

Edu, O. K. (2016). A Critical Analysis of the Laws of Inheritance in the Southern States of 
Nigeria. Journal of African Law, 60, 141-155. https://doi.org/10.1017/S0021855315000133

Enemo, I. P. (2008). Legal Implications of "Bride Price" or "Dowry" on Women's Human Rights in Nigeria. In J. N. Ezeilo, \& J. E. Alumanah (Eds.), Bride Price and the Implications for Women's Rights in Nigeria (pp. 23-40). Enugu: Women Aid Collective.

Ezeilo, J. N. (2004). Towards a Cross-Cultural Approach to Women's Human Rights. In J. N. Ezeilo, M. T. Ladan, \& A. Afolabi-Akiyode (Eds.), Sharia Implementation in Nigeria: Issues \& Challenges on Women's Rights and Access to Justice (2nd ed., pp. 86-101). Enugu/Abuja/Port Harcourt: Women's Aid Collective (WACOL)/Women's Research and Documentation Centre (WARDC).

Ezeilo, J. N. (2013/2014). African Customary Law and the Polarization of Women's Rights as Anti-Africa. Journal of Health Law and Reproductive Rights, 4, 88-120.

Ezeilo, J. N. (2018). Are We Born Free and Equal? Law, Justice and Human Rights in Nigeria/The 144th Inaugural Lecture of the University of Nigeria. Nsukka: University of Nigeria.

Ezeilo, J. N., \& Alumanah, J. E. (2008). Bride Price and the Implications for Women's Rights in Nigeria. Enugu: Women Aid Collective.

Ezeilo, J. N., \& Nwadioke, N. (2008). Women and Marriage: Legal and Social Dimensions. In J. N. Ezeilo, \& J. E. Alumanah (Eds.), Bride Price and the Implications for Women's Rights in Nigeria (pp. 1-22). Enugu: Women Aid Collective.

Ezer, T. (2016). Forging a Path for Women's Rights in Customary Law. Hastings Women's Law Journal, 27, 65-86.

Fenrich, J., \& Higgins, T. E. (2001). Promise Unfulfilled: Law, Culture, and Women's Inheritance Rights in Ghana. Fordham International Law, 25, 259-341.

Gordon, R. (2005). On the Perniciousness of Inheritance Problems. In Gender Research and Advocacy Project/Legal Assistance Centre (Eds.), The Meanings of Inheritance: Perspectives on Namibian Inheritance Practices (pp. 1-22). Windhoek: Legal Assistance Centre.

Kutsoati, E., \& Morck, R. (2012). Family Ties, Inheritance Rights, and Successful Poverty Alleviation: Evidence from Ghana (pp. 1-50). NBER Cambridge Working Paper Series No. 18080. http://www.nber.org/papers/w18080 https://doi.org/10.3386/w18080

Levy, S. K., \& Pinto, M. (2011-2012). Property and Belongingness: Rethinking Gender-Biased Disinheritance. Texas Journal of Women and the Law, 21, 119-152.

Mann, K. (1991). Women, Landed Property, and the Accumulation of Wealth in Early Colonial Lagos. Signs, 16, 682-706. https://doi.org/10.1086/494699

McGregor-Lowndes, M., \& Frances, H. (2008). Every Player Wins a Prize? Family Provision Applications and Bequests to Charity. Brisbane: Queensland University of Technology/The Australian Centre for Philanthropy and Nonprofit Studies.

Mercy Law Resource Centre (2018). Second Right to Housing Report: The Right to Housing in Comparative Perspective.

Nelson, E. E., \& Nelson, I. E. (2010). Violence against Women in Nigeria: The Factors and the Dynamics. Journal of Constitutional Development, 10, 77-96.

Nwogugu, E. I. (2014). Family Law in Nigeria (3rd ed.). Ibadan: HEBN.

Nwoke, M. B. (2008). Bride Price and the Implications for Women's Rights in Nigeria: Psychological Perspective. In J. N. Ezeilo, \& J. E. Alumanah (Eds.), Bride Price and the Implications for Women's Rights in Nigeria (pp. 77-86). Enugu: Women Aid Collective. https://doi.org/10.4314/gab.v7i1.45030 
Nwufo, C. C., \& Okoli, C. K. (2016). Rights of Women to Inheritance under the Nigerian Laws. Nigerian Law Journal, 19, 201-224.

Obi, M. A. O. (2008). A Theoretical Analysis of the Socio-Economic and Political Implications of Bride Price on the Nigerian Woman. In J. N. Ezeilo, \& J. E. Alumanah (Eds.), Bride Price and the Implications for Women's Rights in Nigeria (pp. 63-76). Enugu: Women Aid Collective.

Odiaka, N. O. (2013). The Concept of Gender Justice and Women's Rights in Nigeria: Addressing the Missing Link. Afe Babalola University Journal of Sustainable Development, Law and Policy, 2, 190-205.

Office of the United Nations High Commissioner on Human Rights. The Right to Adequate Housing, Fact Sheet No. 21/Rev. 1.

Ojikere, A., \& Chuan, G. C. (2015). Learning from the Indian Judiciary: New Directions for Securing Nigerian Women's Right to Dignity. Asian Women, 31, 81-105. https://doi.org/10.14431/aw.2015.03.31.1.81

Okoboh, C. O. (2005). Women and Their Right to Property in Nigeria: A Revisit. Igbinedion University Law Journal, 3, 60-72.

Olomola, O. (2010). Competing Interests over Family Property: The Rights or Plights of the Nigerian Woman. Akungba Law Journal, 1, 250-269.

Onyeneho, N. G. (2008). Reproductive Health Rights and Behaviour of Mbaise Women: The Bride Price Factor. In J. N. Ezeilo, \& J. E. Alumanah (Eds.), Bride Price and the Implications for Women's Rights in Nigeria (pp. 95-114). Enugu: Women Aid Collective.

Rautenbach, C., \& Meyer, M. M. (2010). Lost in Translation: Is a Spouse a Spouse or a Descendant (or Both) in Terms of the Reform of Customary Law of Succession and Regulation of Related Matters Act? South African Law Journal, 2012, 149-160.

UN-HABITAT (2006). Progress Report on Removing Discrimination against Women in Respect of Property \& Inheritance Rights: Tools on Improving Women's Secure Tenure Series 1 (Number 2).

Vaquer, A. (2010). Freedom of Testation, Compulsory Share and Disinheritance Based on Lack of Family Relationship (pp. 1-16). Consolidated Research Group Essays 2009 SGR689.

Williams, L. (2014). The Right to Housing in South Africa: An Evolving Jurisprudence. Columbia Human Rights Law Review, 45, 816-845.

\section{Statutes/International Instruments}

Administration and Succession (Estate of Deceased Persons') Law (1986) Cap 4 Laws of Anambra State 1991.

Convention on the Elimination of All Forms of Discrimination against Women 1979 (CEDAW).

Convention on the Elimination of All Forms of Racial Discrimination 1965 (CERD).

Convention on the Rights of Persons with Disabilities 2008 (CRPD).

Convention on the Rights of the Child 1989 (CRC).

Convention Relating to the Status of Refugees CRSR 1952.

Evidence Act 2011 Cap E14 Laws of the Federation of Nigeria 2011(2012 Supplement).

International Convention on the Protection of the Rights of All Migrant Workers and Members of Their Families 1990 (ICPMWMF).

Land Use Act 1978 Cap L5 Laws of the Federation of Nigeria 2011. 
The Federal Republic of Nigeria 1999 Constitution.

Widowhood Law 2005 (Anambra State).

\section{Cases}

Airtel Networks Ltd. v George [2015] 4 NWLR (Pt. 1448) 60.

Anekwe v Nweke [2014] 9 NWLR (Pt. 1412) 393.

Asika v Atuaya [2008] 17 NWLR (Pt. 1117).

Johnson v Ogunbi (1980) 4 CA 277 at 299.

Kolade v Ogundokun [2017] 18 NWLR (Pt. 1596) 152.

Mohammedv Klargester (Nig) Ltd [2002] 14 NWLR (Pt. 787) 335.

Mojekwu v Ejikeme [2000] 5 NWLR (Pt).

Mojekwuv Iwuchukwu [2004] 11 NWLR (Pt. 883) 196.

Mojekwu v Mojekwu [1997] 7 NWLR (Pt. 512) 425.

Nezianya v Okagbue 1963) 1 All NLR 352.

Nzekwu v Nzekwu [1989] NWLR (Pt 104) 373.

Obusez v Obusez [2001] 15 NWLR (Pt. 736) 377.

Odiari v Odiari [2009] 11 NWLR (Pt. 1151) 26.

Okonkwo v Okonkwo [2014] 17 NWLR (Pt. 1435) 18.

Okonyia v Ikengah [2001] FWLR (Pt. 53) 158 at 186; 2 NWLR (Pt. 697) 336.

Ruthlinz Inter' I Invest. Ltdv Stella Ihebuzor [2016] 11 NWLR (Pt1524) 409. 